\title{
THE FIRST REPORT OF PESTALOTIOPSIS SP. CAUSING CROWN ROT DISEASE ON STRAWBERRIES IN DALAT
}

\author{
Le Dung ${ }^{a^{*}}$, Nguyen Thi Dien ${ }^{\mathrm{b}}$, Phan Hoang Daic, Pham Ngoc Tuan ${ }^{\mathrm{a}}$ \\ ${ }^{a}$ The Faculty of Agriculture and Forestry, Dalat University, Lamdong, Vietnam \\ ${ }^{b}$ The Sub-department of Plant Protection and Cultivation, Thaibinh, Vietnam \\ 'Institute of Research and Hi-tech Application in Agriculture, Dalat University, Lamdong, Vietnam \\ Article history \\ Received: June $02^{\text {nd }}, 2016$ \\ Received in revised form $\left(1^{\text {st }}\right)$ : July $02^{\text {nd }}, 2016 \mid$ Received in revised form $\left(2^{\text {nd }}\right)$ : August $02^{\text {nd }}, 2016$ \\ Accepted: August 28 ${ }^{\text {th }}, 2016$
}

\begin{abstract}
Study on the pathogens causing strawberries crown rot disease was complied with the methodology of Koch. Results from isolating 150 samples of infected plant parts collected from three strawberry cultivated areas in Dalat (Ward 7, Ward 8 and Ward 12) indicated that there were 327 isolates belonging to six fungal species. Most fungi isolated from infected parts were identified as Botrytis cinerea, Verticillium sp., Cylindrocarpon destructans, Fusarium oxysporum, Rhizoctonia sp. and Pestalotiopsis sp., in which the main fungi consistently isolated were Pestalotiopsis sp.. By fulfilling Koch's postulates, the results of pathogenesis test indicated that Pestalotiopsis sp. was a pathogen causing the crown rot disease on strawberries in Dalat. This is the first report on the association of Pestalotiopsis sp. with crown rot disease of strawberries in Vietnam.
\end{abstract}

Keywords: Crown rot disease; Pathogens; Pestalotiopsis sp.; Strawberry.

\section{INTRODUCTION}

Strawberries (Fragaria x ananassa Duch.) are a high value crop of economy and nutrition. In Vietnam, strawberries are mainly grown in Dalat, where the average elevation is 1,500 meters above sea level with a cool climate all year round, average temperature being of about $18-21^{\circ} \mathrm{C}$, and soil having favorable conditions for cultivation of vegetables. Although not being grown into concentrated specialized areas, strawberries have become one of the specialty crops of Dalat. The annual economic value from strawberry has been superior to other crops.

In recent years, the area of strawberries in Dalat tends to decline dramatically because of the disease development. Specifically, the area of strawberry cultivation dropped sharply from 125 hectares in 2006 to approximately 40 hectares in 2012. As a 
result, the yield of strawberries also decreased from $40 \mathrm{~kg} / 1,000 \mathrm{~m}^{2}$ per two days to 15 $20 \mathrm{~kg} / 1.000 \mathrm{~m}^{2}$ per two days, the losses were up to $50 \%$ of the strawberry productivity. The most common recognized symptom recently was when strawberries are in the fruiting period, the young leaves suddenly dried up from the edge of the leaf inwards, the older leaves mottled explosion. These symptoms gradually spread down to the crowns. The crowns tended to dry and eventually died; the roots turned blackdish, with the crown core and vascular tissues being discolored of dark brown. The phenomenon spread rapidly on the field and led to mass mortality of strawberries. The disease grew and destroyed the crown, with clearly discoloring of crown vascular tissue into brown or pinkish.

Many pathogens of strawberries have been recorded over the world. The common diseases were mainly crown, stem, root and fruit diseases. In particular, crown rot disease could be caused by many types of pathogens such as Phytophthora cactorum Colletotrichum acutatum, C. gloeosporioides, C. fragaria. The disease was first recorded on strawberries in Florida in Brooks's report in 1931. In 1935, C. fragaria was responsible for wilting of strawberry. In 1960, C. gloeosporioides also been found to cause similar symptoms and eventually discovered C. acutatum (Milholland \& Delp, 1981; Michael \& Ellis, 2008; Bonde et al., 2009; Smith \& Black, 1990). Recent research also showed that Verticillium sp. was the causal agent of wilting symptom on strawberry foliar (Thomas et al., 2009).

Currently, the disease situation has been becoming very complicated, while the lack of effective control measures has been causing strawberry farmers to turn to cultivation of other crops grudgingly. The disease was very difficult to solve for strawberry farmers and local extension agents. In addition, there was no scientific publication about the pathogens of this disease in Vietnam up to now.

The symptoms of disease observed on the field are similar to the studies reported in the world. However, there should be an accurate view with a high scientific value about the causal agent of crown rot in the actual situation. Therefore, this study was to 
find out the pathogen of this disease as a basis for further studies on disease management measures efficiently.

\section{MATERIALS AND METHODS}

The etiological study of crown rot disease on strawberries was conducted as the steps of the Koch's postulates (Koch, 1884).

\subsection{Observation symptoms and sampling}

The typical symptoms were recognized by field surveys and farmer interviews. Sampling was conducted at the main growing areas of strawberry at Wards 7, 8 and 12, Dalat in 2012. The strawberry variety "My Da" (Fragaria $x$ ananassa Duch.) in the farms at the age of 1-5 years, each with an area of $1,000 \mathrm{~m}^{2}$ or more was considered to sample on surveys.

The diseased plants were collected according to Nguyen and Pham's method (2006). At each site, 10 plants with typical symptoms of the disease as described by farmers were sampled. The samples were then taken to the laboratory (Crop protection Lab, Dalat University, Vietnam) for isolation of causal agent of diseases and further studies.

\subsection{Isolation of pathogens}

To isolate present microorganisms from the collected samples, different parts of the infected plant were used, including leaves, flowers, stems, stalks and roots (Ocean, 1988) collected from all three sampling areas. Diseased samples were cut into small specimens, washed of impurities dirt under running water before disinfesting with a solution of $1 \%$ chloramine-B for 5 minutes and then rinsed 3 times with sterile distilled water (Wei \& Su, 2004).

The sterilized specimens were cut into small pieces of $0.5 \times 0.5 \mathrm{~cm}$ (for the leaves), sliced $0.1 \mathrm{~cm}$ (crown), long $0.5 \mathrm{~cm}$ (stalks and roots), and flowers are cut along the calyx. These pieces were cultured on the plates of PDA and incubated at room temperature conditions (ap. $25^{\circ} \mathrm{C}$ ). The frequency of microorganisms was determined 5 
days after incubation. The microbial isolates were identificated by morphological structures observed under a microscope with a magnification of $\mathrm{x} 10$ and $\mathrm{x} 40$.

\subsection{Pathogenesis test}

Pestalotiopsis sp. presented mainly in all the isolated parts. The inoculation by spore suspension was prepared (15-day-old, on PDA) by the method of Stall and Walte (1965). The free-disease strawberry variety "My Da" at 3 weeks old, planted in plastic pots $(10 \mathrm{~cm}$ in diameter) with sterile substrates (soil mixed with coco peat at the rate of 1:2 (v/v)) were inoculated by spraying spore suspension of Pestalotiopsis sp. $\left(10^{7}\right.$ spores $/ \mathrm{ml}$ ). At the same time, strawberries of control treatment were sprayed with tap water only.

The treated plants were sprayed with tap water to ensure regular humidity at 95$100 \%$ till 48 hours after inoculation. Monitoring and recording symptoms on the leaves were examined at 12, 24, 48, and 72 hours after inoculation. Disease symptoms were observed and evaluated after 7-day inoculation. The symptomatic strawberries were also re-isolated to fulfill the steps of etiology studying as Koch's postulates.

\subsection{Data analysis}

All data collected from survey and laboratory studies were processed by Excel 2010 and R software.

\section{RESULTS AND DISCUSSIONS}

\subsection{Symptomatology}

The typical symptoms observed from diseased strawberry were the drying begins from the edge of the leaves. Lesions appear first on the leaves and spreads down the crown. The severely infected plants had completely dried leaves and flowers, then turned dark in color, stems and roots are black (Figure 1).

The disease also spread to all runners. Diseased plants may appear magenta stolon and leaves. The disease was relatively so common that incidence area has been increasing rapidly. 


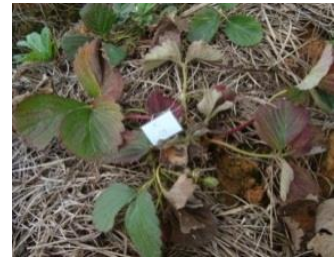

(a)

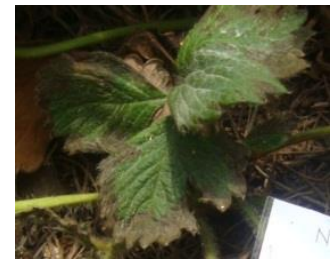

(b)

Figure 1. Diseased symptoms on the field

Note: (a) Diseased plant; (b) On the leaf

\subsection{Isolation and identification of the fungal microorganisms}

The results of isolating from 150 samples of diseased parts with typical symptoms from the three strawberry growing areas (Wards 7, 8 and 12) obtained 327 isolates belonging to six fungi species, namely I1, I2, I3, I4, I5, and I6. The frequency of those funguses was very different among sample parts in the survey areas (Table 1).

Pestalotiopsis sp. (I1) was the fungi with the highest frequency in all diseased parts at the three survey areas. The rate of Pestalotiopsis sp. isolated from leaves was $80.7 \%, 68 \%, 70 \%$ at Wards 8,7 and 12, respectively, which was the highest figures in total.

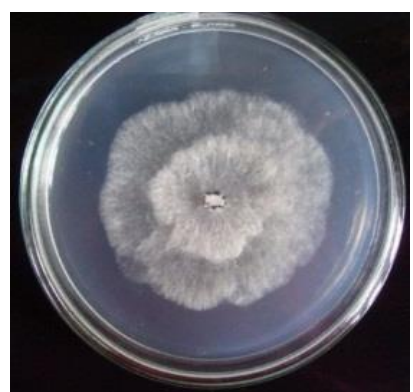

(a)

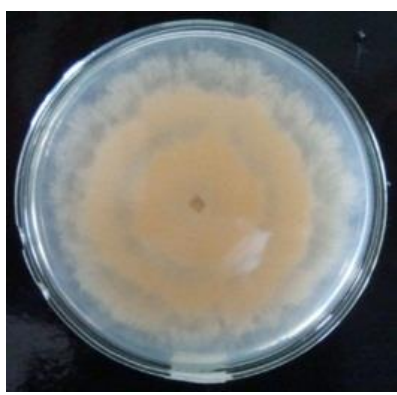

(b)

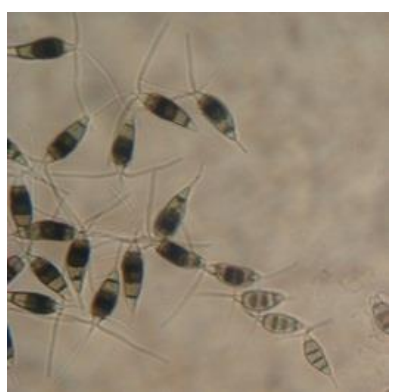

(c)

Figure 2. Morphological features of Pestalotiopsis sp. 5-day-old on PDA.

Note: (a) Front side of colony; (b) Reverse side;

(c) Conidia fusiform with tails at apical cells and basal cells

On PDA media, the colonies of Pestalotiopsis sp. were layered with concentric circles, slightly wavy edges and had a chrysanthemum-shaped. Colony was white to whitish from the edge to the center of colony and cottony, darker with age. Fungal spores formed and concentrated in the black water droplets on the surface colony after 7-day inoculation on PDA media (Figure 2(a,b)). The black water droplets with spores were bigger over time. Conidia formed earlier and more abundant in the region close to 
the center of the colony. The conidia were clavatefusiform, straight or slightly curved, with 4 septa, three median cells were dark brown. Basal cells and apical hyaline cells were transparent, and apical cells with $2-5$ tails (70\% with 3 tails), basal cells with 1-2 tails (2 tails less common) (Figure 2c). These characteristics were really in harmony with those of Pestalotiopsis sp., reported by Guba (1961) and Nag Rai (1993) causing rot disease on strawberry berry in Israel (Howard \& Albregts, 1973). However, the effect of such causal agent on strawberry crowns had investigated extensively.

I2 was isolated with the second frequency level out of the fungus obtained from all parts in 3 sampling areas, exception to roots. Colonies of I2 were circle in shape, and multicellular mycelium was colorless, grew close to the surface of PDA media. The conidia were one-celled, ellipsoid or slightly oval in shape, colorless or pale brown (Figure 3), born on brown branched conidiophores. The black sclerotia, flat or irregular in shape, formed abundantly after 1015 days of inoculation on PDA. These features were similar to the morphology of Botrytis cinerea, a mold responsible for fruit rot in many fruit plants such as strawberries, grapes, cucumbers..., as described by Peng and Sutton (1991) and Sutton (1993).

The present proportions of isolated I3 were relatively low on flowers and roots, particularly lower

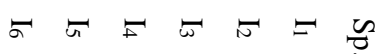

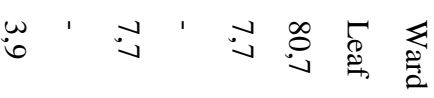

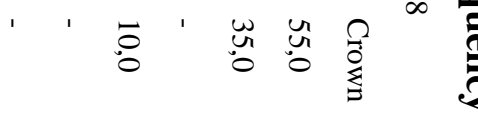

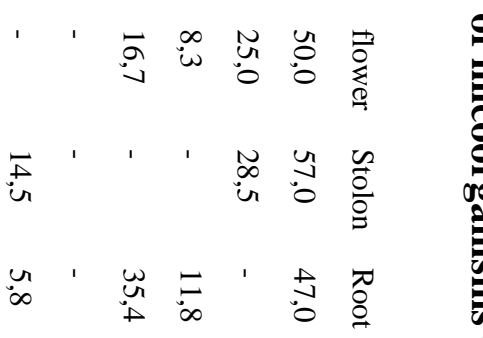

$\overbrace{\frac{a}{2}}^{2}$

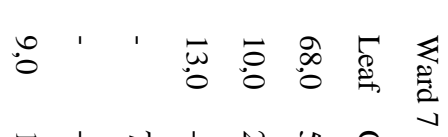
$\vec{O}_{0}^{\prime}$ in '

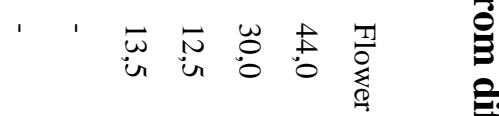

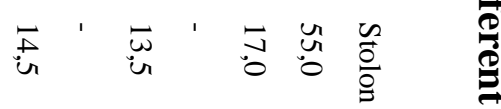

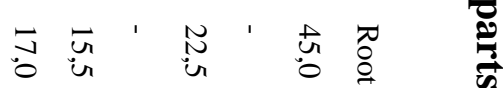
官

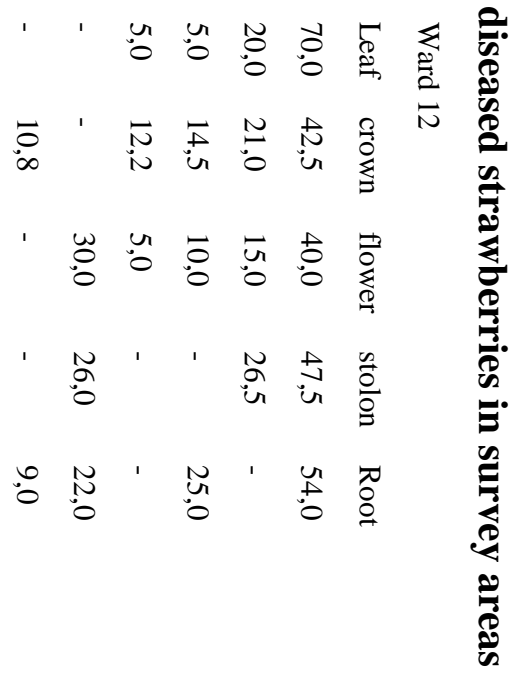
white or yellowish, circle and layered. The contrast 
side was yellow-brown to dark-brown in color.

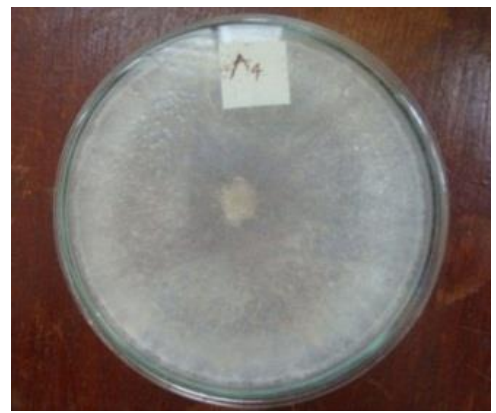

(a)

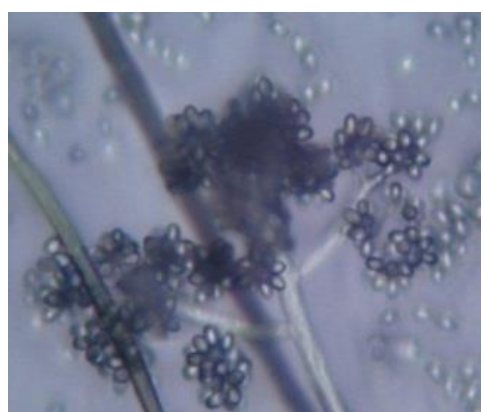

(b)

Figure 3. Morphology of Botrytis cenerea

Note: (a) Colony on PDA; (b) Conidiophore and conidia

The hyphae was aerial (Figure 4a), colorless and septate. Colorless monocellular conidia were elliptic or slightly rounded in shape (Figure 4c), formed on conidiophores at the areas of heads of their sterigmas (Figure 4b). These figures were consistent with the morphological structures of Verticillium sp. as described by Lord and Smith (1994). Verticillium sp. was known as a causal agent of wilt diseases in common annual agricultural crops.

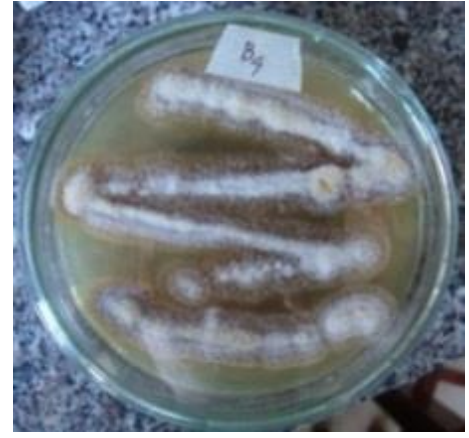

(a)

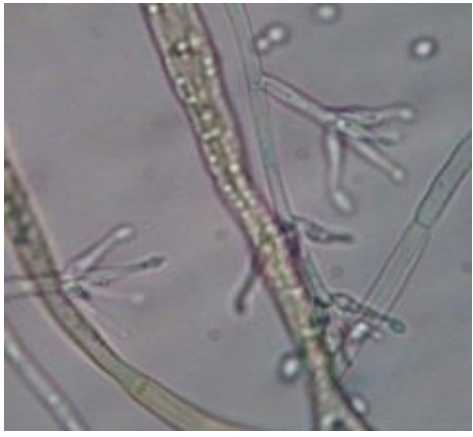

(b)

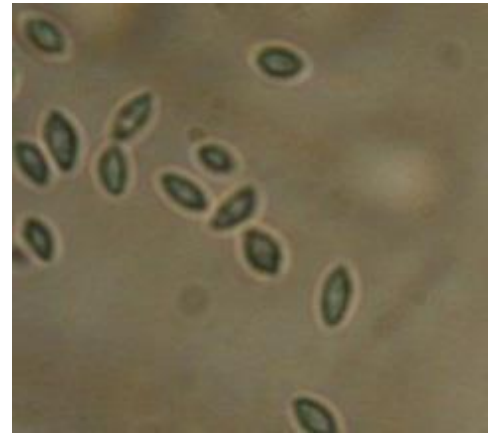

(c)

Figure 4. Morphology of Verticillium sp.

Note: (a) Colony on PDA; (b) Conidiophore with sterigmas and conidia; (c) Conidia

I4 species appeared in all three areas, but at a very low rate in Ward 12. Colonies were dark-brown in both sides upper and the reverse sides. Aerial mycellium spread on the agar surface, branched, with long singly conidiophore. The macroconidia were hyaline, elongated elliptic, or cylindrical with rounded ends and 1-3 septate (Figure 
5(b,c,d)). Similar figures to those of Cylindrocarpon destructans described by Booth (1966).

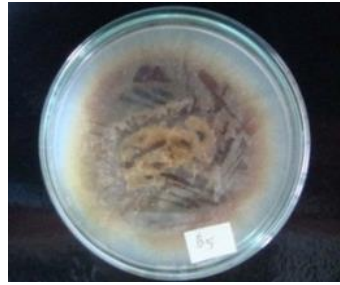

(a)

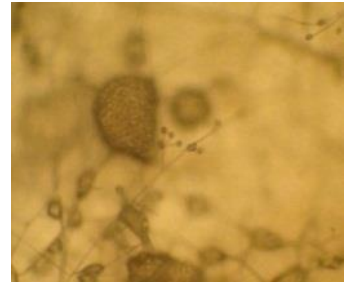

(b)

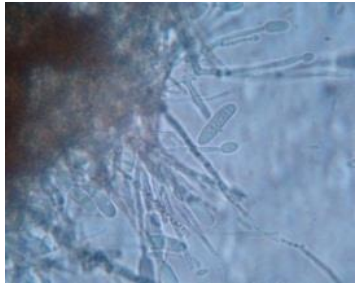

(c)

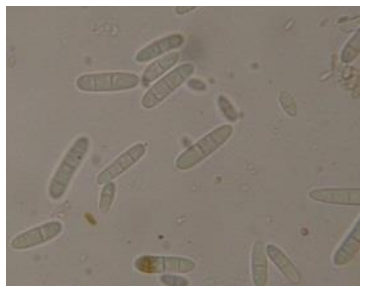

(d)

Figure 5. Morphology of Cylindrocarpon destructans

Note: (a) Colony of 14-days-old C. destructans on PDA; (b) Abundant macroconidia; (c) Phialides; (d) Microconidia and macroconidia.

The figures for I5 were relatively large in Ward 12 with the proportion of up to $30 \%$ of flowers, followed by those on stolon and roots, accounted for 26 and $22 \%$, respectively. Whereas, $15.5 \%$ was the frequency of this fungus on roots collected at Ward 7. On PDA media, the radial colony of I5 initially appeared light brown and later turned to dark brown with aerial mycelium (Figure 6a).

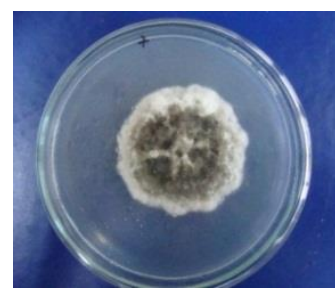

(a)

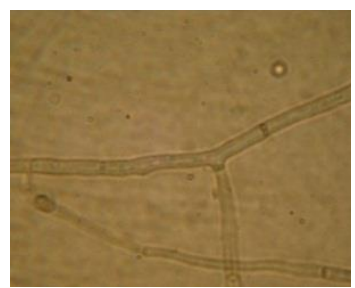

(b)

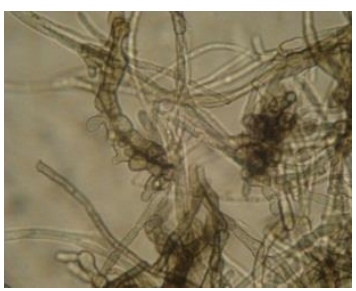

(c)

Figure 6. Morphology of Rhizoctonia sp.

Note: (a) Colony on PDA; (b) T-type of mycelium - Typical Rhizoctonia sp. mycelium showing its branching at a right angle and septa close to the branch origin; (c) Hyphae and monilioid cells

The hyphae in culture was initially hyaline or silvery becoming yellow and brown with age, septate, with 90 degree branching (T-type branching), constriction and septum close to origin of branch. Hyphal cells had multinuclears with 3 to 8 nuclei per cell. Another form of mycelium was monilioid cells obtained from microscope observations (Figure 6(b,c)). The morphology figures of fungus observed in the study were line in with those reported by Dasgupta (1992), Parmeter et al. (1970) and Vu (2007) about Rhizoctonia sp. This was quite a common causal pathogen such as collar rot of crucifers, seedling roots wilting, rice sheath blight... However, it was not common 
to isolate this fungus from strawberry roots and was not consistently pathogenic (Martin, 1988).

I6 colony were circle, white in color, and turned purplish with age (Figure 7(a,b)). Mycelium were baffled, cottony, without exudate. Microconidia were small, egg-shaped or elongated and slightly pointed or extended ovals with or without septum (0-1 septum), formed on typical single short monophyalides or abundantly on false heads on short conidiophores.

Macroconidia were larger, elongated and both pointed ends, or curved sickle, with 3-5 septa (Figure 7(c,d,e)). There was an appearance of thick-walled chlamydospores, transparent, circular in shape, formed singly or in pairs 1-month after inoculation on PDA (Figure 7f). The results were consistent with observed morphological description of Fusarium oxysporum in the literatures of Booth (1977).

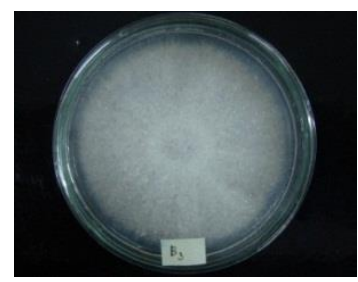

(a)

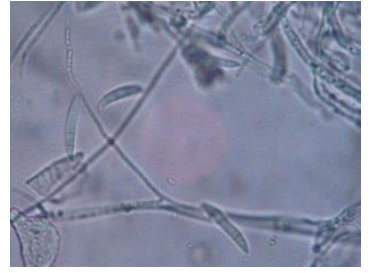

(d)

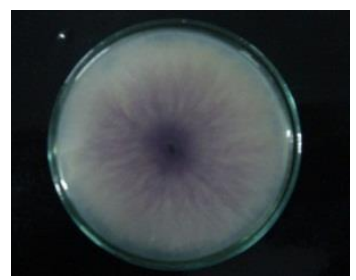

(b)

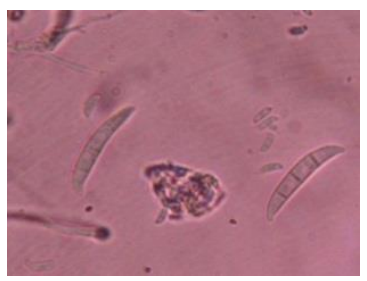

(e)

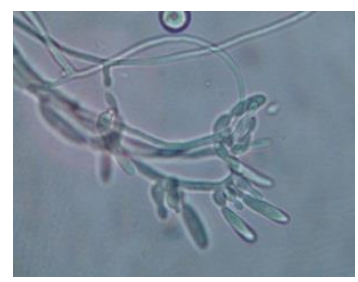

(c)

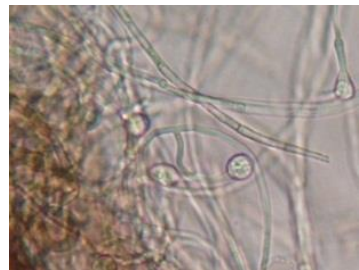

(f)

\section{Figure 7. Morphological characteristics of Fusarium oxysporum on PDA}

Note: (a,b) The colony front side A, and contract side B; (c,d) Conidiospore and macroconidia;

(e) Microconidia and macroconidia; (f) Chlamydospore

Thus, the causal pathogen with the highest frequency was Pestalotiopsis sp., and their ability were to cause the symptoms found on the field. This is the basis for further study to proceed to the next experiment. 


\subsection{Pathogenesis test}

After isolation and determination of the fungus frequency on strawberries with the typical symptoms, Pestalotiopsis sp. was of the highest frequency in all three survey areas. The results of pathogenesis test for Pestalotiopsis sp. indicated as follows:

Young leaves started to appear drying at the leaf edge after 48 hours of inoculation. The lesions continued to grow rapidly over time. By 72 hours after inoculation, the lesion on the young leaves developed up to half the area of leaves, the symptoms were also observed on old leaves with green leaf edge. After 7 days of inoculation, inoculated plants completely wilted, lesions began to turn dark-brown with symptoms similar to those on the survey fields. The controlled plants (sprayed with tap water only) meanwhile remained in normal development (Figure 8b), and these diseased symptoms were not observed. To fulfill the test, the diseased leaves were incubated and the agent caused the symptoms were also re-isolated in PDA. The experiments were repeated three times. These results concluded that Pestalotiopsis sp. were responsible for observed symptoms of crown rot on the strawberries in Dalat (Figure 8(a,b,c,d)).

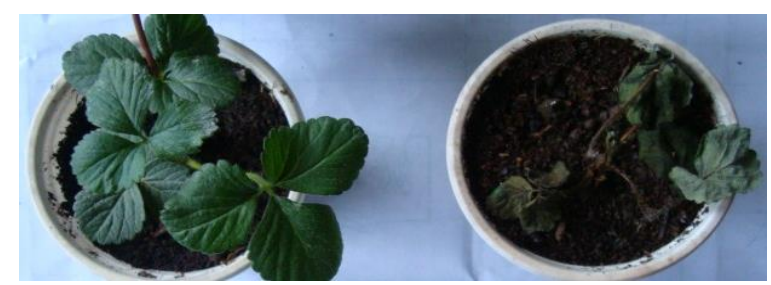

(a)

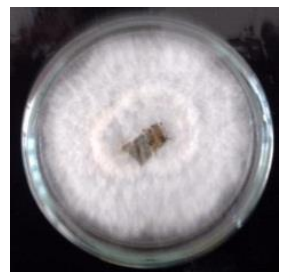

(b)

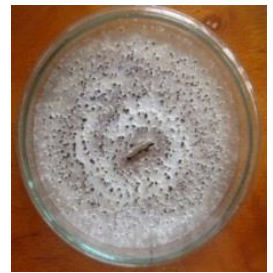

(c)

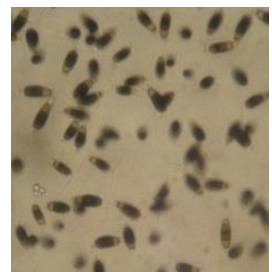

(d)

Figure 8. The result of pathogenesis test

Note: (a) After 7 days of inoculation (left: control, right: inoculated plant); (b,c,d) Morphology of Pestalotiopsis sp. from re-isolating

In Vietnam, there is no public report of Pestalotiopsis sp. on strawberries up to now. These fungi were only recognized as the causal agent of leaf spot disease on coconut trees (Vo, 2006), or grey blight disease of teas (Dance, 2007), and other 
diseases such as cashew leaf spot and mango leaf spot. In the world, Pestalotiopsis sp. were reported as causing agent of fruit rot disease of strawberry. Strawberry rot caused by $P$. longisetula Cuba, was first recognized in Israel, USA (Howard \& Albregts, 1973) and was also discovered in India later. In Egypt, these fungi have caused rotting of strawberry fruits on the field. The disease usually raised and damaged severely at special conditions such as low temperatures and high humidity as well as in rainy and cold season.

\section{CONCLUSION}

Pestalotiopsis sp. were the fungi with the highest frequency on all parts of strawberry plants with symptoms of crown rot disease in the sampling area. By fulfilling Koch's postulates, this study can reach the conclusion that Pestalotiopsis sp. were causal agent of crown rot disease on strawberries in Dalat. This is the first report on Pestalotiopsis disease of strawberries in Vietnam.

\section{REFERENCES}

Bonde, M. R., Peterson, G. C. \& Maas, G. L. (1991). Isozyme comparisons for identification of Colletotrichum spp. pathogenic to strawberry. Phytopathology, $81,1523-1528$.

Booth, C. (1977). The genus Fusarium. Surrey, England: Mycological Institute.

Booth, C. (1966). The genus Cylindrocarpon. Surrey, England: Mycological Institute.

Dasgupta, M. K. (1992). Rice sheath blight: The challenge continues. In: Singh, U.S., Mukhopadhyay, A.N., Kumar, J. \& Chaube, H.S. (Eds.), Plant diseases of international importance: Disease of cereals and pulses. New Jersey, England: Prentice Hall Englewood Cliffs.

Delp, B. R. \& Milholland, R. D. (1981). Susceptibility of strawberry cultivars and related species to Colletotrichum fragariae. Plant Dis. 65, 421-423.

Duong H. D. (1988). A manual of plant bacterial research. Maxcova, Rusia: Mir Maxcova Publisher.

Guba, E. F. (1961). Monograph of Monochaetia and Pestalotia. Massachusetts, USA: Harvard University Press.

Howard, C. M. \& Albregts, E. E. (1973). A strawberry fruit rot caused by Pestalotia longisetula. Phytopathology, 63, 862-863.

Koch, R. (1884). Die Aetiologie der Tuberkulose: Mitt Kaiser Gesundh.

Le, L. T. \& Vu, T. M. (1998). Plant pathology. Hanoi, Vietnam: Agricultural Publisher. 
Lord, W. G. \& Smith, C. A. (1994). Verticillium Wilt of strawberry: University of New Hamshire Cooperative Extension.

Martin, S. B. (1988). Identification, isolation frequency, and pathogenicity of anastomosis groups of binucleate Rhizoctonia spp. from strawberry roots. Phytopathology, 78, 379-384.

Michael, A. E. (2008). Strawberry leaf disease: The Ohio State University.

Nag Raj, T. R. (1993). Coelomycetous Anamorphs with appendage-bearing conidia. Waterloo, Ontario, Canada: Mycologue Publications.

Nguyen, T. L. \& Pham, T. D. (2006). Textbook of research methodology. Hanoi, Vietnam: Agricultural Publisher.

Parmeter, J. R. Jr., Whitney, H. S. \& Platt, W. D. (1970). Affinities of some Rhizoctonia species that resemble mycelium of Thanetephorus cucumeris. Phytopathology, $57,218-223$.

Peng, G. \& Sutton, J. C. (1991). Evaluation of microorganisms for biocontrol of Botrytis cinerea in strawberry. Can. J. Plant Path., 13, 247-257.

Smith, B. J. \& Black, L. L. (1990). Morphological, cultural, and pathogenic variation among Colletotrichum species isolated from strawberry. Plant Dis., 74, 69-76.

Stall, R. E. \& Walte, J. M. (1965). Selection and inheritance of resistance in tomato to isolate of race 1 and 2 of fusarium wilt organism. Phytopathology, 55, 12131215.

Sutton, J. C. (1993). Biocontrol of Botrytis cinerea in strawberry leaves. Phytopathology, 83, 615-621.

Thomas, R. G. \& Krishna, V. S. (2009). Verticillium wilt of strawberry. California Strawberry Commission.

Vo, T. H. (2006). Plant pathology. Cantho: Cantho University.

Vu, T. M. (2007). Plant pathology textbook. Hanoi: Publisher of The University of Agriculture and Forestry I.

Wei, J. G. \& Xu, T. (2004). Pestalotiopsis kunmingensis sp. nov., an endophyte from Podocarpus macrophyllus. Fungal Diversity 15, 247 - 254. 


\section{PESTALOTIOPSIS SP. - TÁC NHÂN GÂY BÊNH KHÔ LÁ CÂY DÂU TÂY (FRAGARIA $x$ ANANASSA DUCH.) TẠI ĐÀ LẠT}

\section{Lê Dũnga*, Nguyễn Thị Diên ${ }^{\mathrm{b}}$, Phan Hoàng Đạic, Phạm Ngọc Tuâna}

${ }^{a}$ Khoa Nông Lâm, Truờng Đại học Đà Lạt, Lâm Đồng, Việt Nam

${ }^{b}$ Chi cục Bảo vệ Thực vật và Trồng trọt tỉnh Thái Bình, Thái Bình, Việt Nam

${ }^{c}$ Viện Nghiên cứu và Úng dụng Nông nghiệp Công nghệ cao, Truờng Đại học Đà Lạt, Lâm Đồng, Việt Nam

*Tác giả liên hệ: Email: dungl@dlu.edu.vn

\section{Lịch sử bài báo}

Nhận ngày 02 tháng 06 năm 2016

Chỉnh sửa lần 01 ngày 02 tháng 07 năm 2016 | Chỉnh sửa lần 02 ngày 02 tháng 08 năm 2016 Chấp nhận đăng ngày 28 tháng 08 năm 2016

\section{Tóm tắt}

Nghiên cưu tác nhân gây bệnh khô lá trên giống dâu tây Mỹ Đá (Fragaria x ananassa Duch.) được thưc hiện tuân theo các bước của định đề Koch. Kết quả phân lập tù̀ 150 mẫu bộ phận của cây bệnh thu thập tù 3 vùng khác nhau (Phwờng 7, Phwờng 8 và Phuờng 12) tại Đà Lạt thu được 327 mẫu vi sinh vật thuộc 6 loài nấm. Tất cả các mẫu nấm phân lập tù các bộ phận bị bệnh đã được định danh là Pestalotiopsis sp., Verticillium sp., Botrytis cinerea, Cylindrocacpon destructans, Fusarium oxysporum, và Rhizoctonia sp.. Trong đó, Pestalotiopsis sp. là loài có tần xuất hiện diện cao nhất ở tất cả các bộ phận cây bệnh của cả ba vùng lấy mẫu. Tính gây bệnh của Pestalotiopsis sp. cũng được đánh giá trên cây dâu tây giống Mỹ Đá và kết quả cho thấy Pestalotiopsis sp. chính là tác nhân gây bệnh khô lá trên cây dâu tây tại Đà Lạt. Đây được xem là báo cáo đầu tiên về Pestalotiopsis sp. gây bệnh trên cây dâu tây tại Việt Nam.

Từ khóa: Bệnh khô lá; Cây dâu tây; Pestalotiopsis sp; Tác nhân gây bệnh. 